\title{
Copyright and Copyright Protection
}

\author{
Safet Emruli \\ $\mathrm{PhD}$ in law, professor at Faculty of law, State University of Tetova, \\ St. Ilinden nn, 1200 Tetovo, Republic of Macedonia
}

Agim Nuhiu

$\mathrm{PhD}$ in law, professor at Faculty of law,

State University of Tetova, St. llinden nn, 1200 Tetovo, Republic of Macedonia

Besa Kadriu

MSc in law, Faculty of law, South East European University, St. llinden no 335, 1200 Tetovo, Republic of Macedonia

Abstract

One of the legal intellectual property disciplines are copyrights which concerns artistic and literary works. Copyright is: bundle of exclusive legal rights that has to do with protection of literary and artistic works. It is granted to authors and artists to protect expressive works against unauthorized reproduction or distribution by third parties. Copyright protect "works", expression of thoughts and ideas. Literary, dramatic, musical and artistic works must be original, it means not to be a copy. Copyright covers two other types of right: economic rights, the right of the owner to benefit financial reward from use of his work by others and moral rights which always have to do with original holder no matter if economic rights are transferred or not. Economic rights can be transferred. Bern Convention for the Protection of the Literary and Artistic Works is international key agreement and the oldest multilateral agreement in the field of copyright. Copyright subsists automatically on the creation of a work, no application needed, nor do any formalities apply. Nature of copyright is territorial and the minimum term of protection is life of the author plus 50 years after his/her death. In European Union and in certain number of countries, terms of protections of are extended to life of the author plus 70 years after his/her death.

Keywords: intellectual property, copyright, protection of copyright, originality.

\section{Introduction}

The term "intellectual property" my sound pretentious, but it is an apt description for subject matter of the laws that give rise to proprietary interests in creations of the mind. The principal one of the legal intellectual property disciplines is copyrights which concerns artistic and literary works. ${ }^{1}$

Copyright is granted to authors and artists to protect expressive works against unauthorized reproduction or distribution by third parties. Expressive works are broadly defined, and include such thinks as books, films music recordings, and computer software. ${ }^{2}$

Article 2 of the Bern Convention for the Protection of the Literary and Artistic Works the expression 'literary and artistic works' shall include every production in the literary, scientific and artistic domain, whatever may be the mode or form of its expression, such as books, pamphlets and other writings; lectures, addresses, sermons and other works of the same nature; dramatic or dramatico-musical works; choreographic works and entertainments in dumb show; musical compositions with or without words; cinematographic works to which are assimilated works expressed by a process analogous to cinematography; works of drawing, painting, architecture, sculpture, engraving and lithography; photographic

${ }^{1}$ R. SCHECHTER and J. THOMAS, Intellectual Property the Law of Copyrights, Patents, and Trademarks, Thomson West, USA, 2003 2 F. ABBOTT, TH. COTTIER and F. GARRY, International Intellectual Property In An Integrated World Economy, Second Edition, USA, 2011, p.9 
works, to which are assimilated works expressed by a process analogous to photography; works of applied art; illustrations, maps, plans, sketches and three-dimensional works relative to geography, topography, architecture or science. [...] Translations, adaptations, arrangements of music and other alterations of a literary or artistic work shall be protected as original works without prejudice to the copyright in the original work [...] Collections of literary or artistic works, such as encyclopaedias and anthologies which, by reason of the selection and arrangement of their contents constitute intellectual creations shall be protected as such, without prejudice to the copyright in each of the works forming part of such collections. ${ }^{1}$ According to this any creation of the mind can attract copyright protection as long as it meets the requirement of the Berne Convention and the requirement of national law. Bern Convention with article 2 specifies that the expressions "literally and artistic works" shall include production in the literary, scientific and artistic domain. One of definition for copyright is: bundle of exclusive legal rights that has to do with protection of literary and artistic works. As we can see, copyright protect "works", expression of thoughts and ideas. Ideas and thoughts can not be subject matter of copyrights. Idea as a idea can be freely copied, example an idea for writing a novel for France aristocracy can be copied as a idea from anyone, but then this idea is expressed in words it gains a protection.

\section{Protection of copyright}

Copyright protect "works", expression of thoughts and ideas. There is no formal definition of "work" but case law suggests that some minimum amount of effort must have been expended in author's creation. Copyright protection has been refused to works which are very trivial or very small. ${ }^{2}$

Work should come within meaning of the concept of "literally and artistic works" in accordance of Article 2 of Berne Convention.

A work of authorship must be original in order to qualify for copyright protection. It means that:

1. the author must have engaged in his own intellectual endeavor, rather than copying from an preexisting surce and

2. the work must demonstrate a minimum amount of creativity. ${ }^{3}$

Literary, dramatic, musical and artistic works must be original, but 'originality' is not defined. This judicially initiated principle has two aspects: a work must emanate from its author, and the author must have exercised a modicum of 'skill, labour, and judgment' in the work's creation. To be original a work must not be a copy. ${ }^{4}$

Copyright confers the exclusive right to reproduce the work, issue copies to the public communicate it or adopt it. It is infringement when one of these acts is done without a permition. ${ }^{5}$

Work is protected by its creation, and in some national legislations "works" have to be fixed before its protection. The work consider fixed when it is written down or recorded. Upon creation or fixation, depending on the national legislation, copyright protection automatically comes into force without further formality. ${ }^{6}$

The author is the person who invests the element of creativity for the creation of the work at issue. And it is usually to whom copyrighted is granted.

The author of copyright enjoys two type of rights economic and moral rights.

\section{Economic rights}

Economic rights are right of the owner to benefit financial reward from use of his work by others. Copyright law traditionally has focused on granting authors economic right in their works.

\footnotetext{
1 Bern Convention for the Protection of Literary and Artistic Works, September 9, 1886, completed on 4 May 1896, revised at Berlin on November 13, 1908, completed at Berne on March 20, 1914, revised at Rome, June 2, 1928, at Brussels on June 1948, at Stockholm July 14, 1967, at Paris July 24, 1971, and amended on September 28, 1979

2 C. COLSTON, Principles of Intellectual Property Law, London, 1999

${ }^{3}$ M. BRRETT Intellectual Property, Third Edition, New York, 2012

${ }^{4}$ C. COLSTON, Principles of Intellectual Property Law, London, 1999

${ }^{5}$ C. COLSON, J. GALLOWAY, Modern Intellectual Property Law, Third Edition, USA, 2010

${ }^{6} \mathrm{~K}$. Idris, Intellectual Property A Power Tool For Economic Growth
} 
By contracts many countries have fashioned their copyright laws to extend such personal, along with economic rights. ${ }^{1}$

Economic rights provided from Bern Convention can be separated in four grups:

Right of reproduction regulated in Article 9 pint 1 of convention which says: authors of literary and artistic works protected by this Convention shall have the exlusive right of authorizing the reproduction of these works in any manner or form. ${ }^{2}$

Right of translation or adaptation. Translation is the right of the author authorizing for translating of his work from one language in other languages. And adaptation means remodeling in another form or adjustment of the work.

Public performance is through public performance , broadcasting and communication to the public and

Resale right

Economic rights can be transferred, it means that third party can obtain economic rights if the rights are been transferred by the author.

It is opposite with the moral rights, they are non-transferable.

\section{Moral rights}

The moral rights protect the integrity of work against unsuitable treatment by others. They are: the right to be named as author, the right to object to derogatory treatment of the work and the right against false attribution. ${ }^{3}$ Regarding this, Article 6 bis of Convention provides two type of moral right:

the right of the paternity identifying the author in each copy of the authors work and

the right of integrity, right of the author to object to any derogation, distortion or other modification to his work which will consist to his honor or reputation.

Copyright protection is territorial in nature which means that for gaining copyright protection firstly you have to meet the requirements of that country in which protection is asked for. If the work meet the requirement for copyright protection than the minimum term of protection under the Trade-Related Aspects of Intellectual Property Rights (TRIPS) agreement, will be life of the author plus 50 years after his/her death. ${ }^{4}$ However, in European Union and in certain number of countries, terms of protections are extended to life of the author plus 70 years after his/her death.

\section{Bern Convention}

Bern Convention for the Protection of the Literary and Artistic Works is international key agreement and the oldest multilateral agreement in the field of copyright. The main purpose of this convention is to harmonize copyright law of Contracting Parties, where the Contracting Parties are obligated to offer authors at least minimum standard of protection provided from this Convention.

Basic principe from this convention are: principe of national treatment, automatic protection and independent of protection. The main princip of the Bern Convention is national treatment. Bern Convention obligate the contracting parties to treat foreign author of the Bern Union same as national authors, ${ }^{5}$ under national law countries can not discriminate against works from other countries part of the convention. Only authors of works protected under the Convention are entitled to national treatment. Under article 5 of the Bern Convention "Authors shall enjoy, in respect of the works for which they are

${ }^{1}$ C. COLSON, J. GALLOWAY, Modern Intellectual Property Law, Third Edition, USA, 2010

2 Bern Convention for the Protection of Literary and Artistic Works, September 9, 1886, completed on 4 May 1896, revised at Berlin on November 13, 1908, completed at Berne on March 20, 1914, revised at Rome, June 2, 1928, at Brussels on June 1948, at Stockholm July 14, 1967, at Paris July 24, 1971, and amended on September 28, 1979 , Article 9 pint 1

${ }^{3}$ M. BRRETT Intellectual Property, Third Edition, New York, 2012

${ }^{4}$ Agreement on Trade-Related Aspects of Intellectual Property Rights, Apr. 15, 1994, Marrakesh Agreement Establishing the World Trade Organization

${ }^{5}$ K. Idris, Intellectual Property A Power Tool For Economic Growth 
protected under this Convention, in countries of Union other than the country of origin, the rights which their respective laws do now or may hereafter grant to their nationals, as well as the rights specially granted by this Convention": ${ }^{1}$

Example

An author who is a national of the contracting states

An author of a novel first published in a contracting state who lives in contracting state but is not a national of a contracting state

An author of piece of architecture erected in contracting state but who does not live there or have an office there

A market of cinematographic works who has a head office in contracting state but is not a national of that state and who does not live there.

The second princip of the Bern Convention is Principle of automatic protection who is regulated by article 5 point 2 which says that: the enjoyment and the exercise of these rights shall not be subject to any formality.

It means that the author can attract a copyright protection without having comply any formalities such as deposits of the work in a National register.

Principe of the independence means that copyright protection of a German novel in Italy is independent of the fact that this novel attracts copyrights protection in Germany or not.

Article 5 point 2 says that: enjoyment and exercise of copyright protection in a work in a Union country is independent of the existence of copyright protection in the country of origin of the work. ${ }^{2}$

\section{CONCLUSION}

Copyright is bundle of exclusive legal rights that has to do with protection of literary and artistic works. A "work" must be original in order to qualify for copyright protection. The owner of copyright may use his protected work as he wishes, same time he can prevent others to use his protected work without authorization. There are two type of rights economic, the right of the owner to benefit financial reward from use of his work by others and moral rights which always have to do with original holder.

For granting a copyright protection there are no formalities or fees, it consist in automatically protection on the creation of a work and the work in protected in that particular territory in which is granted, it means that copyright protection is territorial in nature.

Regarding the protection of copyrights, Bern Convention for the Protection of the Literary and Artistic Works is international key agreement and the oldest multilateral agreement in the field of copyright. The main purpose of this convention is to harmonize copyright law of Contracting Parties.

\section{BIBLIOGRAPHY}

Books:

[1] F. ABBOTT, TH. COTTIER and F. GARRY, International Intellectual Property In An Integrated World Economy, Second Edition, USA, 2011, p.9

[2] M. BRRETT Intellectual Property, Third Edition, New York, 2012

[3] R. SCHECHTER and J. THOMAS, Intellectual Property the Law of Copyrights, Patents, and Trademarks, Thomson West, USA, 2003

\footnotetext{
1 Bern Convention for the Protection of Literary and Artistic Works, September 9, 1886, completed on 4 May 1896, revised at Berlin on November 13, 1908, completed at Berne on March 20, 1914, revised at Rome, June 2, 1928, at Brussels on June 1948, at Stockholm July 14, 1967, at Paris July 24, 1971, and amended on September 28, 1979 , Article 5

2 Bern Convention for the Protection of Literary and Artistic Works, September 9, 1886, completed on 4 May 1896, revised at Berlin on November 13, 1908, completed at Berne on March 20, 1914, revised at Rome, June 2, 1928, at Brussels on June 1948, at Stockholm July 14, 1967, at Paris July 24, 1971, and amended on September 28, 1979 , Article 5 pint 2
} 
[4] C. COLSON, J. GALLOWAY, Modern Intellectual Property Law, Third Edition, USA, 2010

[5] C. COLSTON, Principles of Intellectual Property Law, London, 1999

[6] K. Idris, Intellectual Property A Power Tool For Economic Growth

\section{Laws and Treaties:}

[1] Agreement on Trade-Related Aspects of Intellectual Property Rights, Apr. 15, 1994, Marrakesh Agreement Establishing the World Trade Organization

[2] Bern Convention for the Protection of Literary and Artistic Works, September 9, 1886, completed on 4 May 1896, revised at Berlin on November 13,1908, completed at Berne on March 20,1914, revised at Rome, June 2, 1928, at Brussels on June 1948, at Stockholm July 14, 1967, at Paris July 24, 1971, and amended on September 28, 1979 